\title{
Role of Complementary and Alternative Medicines in Cognition and Anxiety
}

\author{
Yadav M, Akhtar J, Pal R, Dixit RK and Nath R* \\ King George's Medical University, India
}

Submission: May 21, 2018; Published: May 29, 2018

*Corresponding author: Rajendra Nath, Pharmacology, King George’s Medical University, Lucknow (UP), 226003, India, Tel: 9454615783;

Email: rajendra.nath79@gmail.com

Abstract

Dementia in the elderly is an epidemic of unprecedented proportion in modern medicine. An "epidemic" of diseases like Alzheimer's has not yet been met by effective symptomatic treatments or preventative strategies. Among a few current prescription drugs are cholinesterase inhibitors (Donapezil) and N-methyl D-Aspartate receptor antagonist (Memantine). Furthermore multitude of pharmaceutical agents are available for the treatment of mood disorders, anxiety and insomnia, but many patients have difficulty tolerating the side effects, do not respond adequately, or eventually lose their response. Research into ethnobotanicals for memory or cognition and anxiety .has burgeoned in recent years. The herbs that promote especially the intelligence are known as Medhya herbs. Therapeutic herbs and nutrients have far fewer side effects and many provide an alternative treatment or can be used to enhance the effect of prescription medications.

\section{Introduction}

Cognition is a complex process that includes multiple domains, from learning and memory to attention. Dementia is the cognitive impairment by the loss of intellectual ability that hamper occupational functioning, social activities and relationships in the absence of loss of consciousness or with motor involvement [1]. It is estimated that the number of people living with dementia will almost double every 20 years to 42.3 million in 2020 and 81.1 million in 2040 [2]. Anxiety is described as "a psychological, physiological, and behavioral state induced in animals and humans by a threat to well-being or survival, either actual or potential" [3]. Globally as of 2010 approximately 273 million (4.5\% of the population) had an anxiety disorder. It is more common in females (5.2\%) than males (2.8\%) [4].

Number of nootropics drugs has been developed for the treatment of cognitive deficits, from the FDA approved acetylcholinesterase inhibitors (e.g., Donepezil) and NMDA receptor antagonist e.g. Memantine, to those still under development ampakines, nicotinic receptor agonists, glycine inhibitors, and PDE inhibitors [5]. Benzodiazepine, selective serotonin reuptake inhibitor (SSRI), monoamine oxygenase inhibitors (MAOIs), tricyclic antidepressants (TCAs), tranquilizers such as buspirone, beta-blockers are the drugs that are indicated for anxiety disorder.

Now a day's herbal medicine and Complementary and Alternative Medicine (CAM) use is widespread in neurological disorders due to their natural origin and less side-effects. The World Health Organization (WHO) estimates that $80 \%$ of the population uses herbs; in the developing world rates could be as high as 95\% [6]. Medhya Rasayanas are group of medicinal plants in Ayurveda (Indian system of medicine) to improve memory and intellect by Prabhava (specific action). Medhya Rasayana is a group of 4 medicinal plants that are Mandukaparni (Centellaasiatica Linn.), Yastimadhu (Glycirrhiza|glabra Linn.), Guduchi (Tinospora cordifolia and Shankhapushpi (Convolvulus pleuricaulis Chois), can be used singly or in combinations [7].

In practice few more drugs are used as nootropic that are Aindri (Bacopa monniera), Jyothishmati (Celastrus panniculata), Kushmanda (Benincasa hispida), Vacha (Acorus calamus) and Jatamamsi (Nardostachys jatamamsi) [7]. Convolvulus pluricaulis Chois. (Convolvulaceae), also known as Shankhpushpi, has been used traditionally for its memory enhancing, anticonvulsant, anti anxiety, and sedative properties $[8,9]$.

Herbal plants such as passionflower, kava, St. John's wort and valerian root, as well as the amino acid lysine and the cation magnesium, have been used for centuries in Ayurveda and traditional medicine as anti anxiety and to positively enhance $\operatorname{mood}[10]$.

The omega-3 polyunsaturated fatty acids (PUFA) also play an important role in cellular functioning (maintain optimal membrane fluidity) and normal brain cognitive function 
development including learning and memory [11]. The omega-3 PUFA incorporated into the neuron membrane also increase synaptic protein expression, strengthening the hippocampal synaptic plasticity [12].

Due to adverse effects and rising cost of the drugs that available presently, people are switching to complementary therapies which include nutritional supplements like omega-3 polyunsaturated fatty acids, herbal drugs and natural remedies for the management and treatment of psychological conditions.

Cognitive enhancement is in demand, both in healthy populations and those with cognitive deficits. Currently drugs that are available have modest benefits. So much more evaluation has to be done because the aging segment of the population explodes over the upcoming decades, with increasing rates of cognitive decline and neurodegenerative disease. Also we have to evaluate the combined effect of nutritional supplements with the herbal drugs combination to produce optimum desired effect with better compliance.

\section{References}

1. Sharma B, Singh N (2010) Pitavastatin and 4'-hydroxy-3'methoxyacetophenone (HMAP) reduce cognitive dysfunction in vascular dementia during experimental diabetes. Curr Neurovasc Res 7(3): 180-191.

2. Ferri CP, Prince M, Brayne C, Brodaty C, Fratiglioni L, et al. (2005) Global prevalence of dementia: A Delphi consensus study. Lancet 366(9503): 2112-2117.
3. Steimer $\mathrm{T}$ (2002) The biology of fear-and anxiety-related behaviours. Dialogues Clin Neurosci 4(3): 123-137.

4. Kessler RC, Petukhova M, Sampson NA, Zaslavsky AM, Wittchen HU (2012) Twelve-month and lifetime prevalence and lifetime morbid risk of anxiety and mood disorders in the United States. Int J Methods Psychiatr Res 21(3): 169-184.

5. Wallace TL, Ballard TM, Pouzet B., Riedel WJ, Wettstein JG (2011) Drug targets for cognitive enhancement in neuropsychiatric disorders. Pharmacol Biochem Behav 99(2): 130-145.

6. WHO (1993) Research Guidelines for Evaluating the Safety and Efficacy of Herbal Medicines, Manila.

7. Kulkarni R, Girish KJ, Kumar A (2012) Nootropic herbs (Medhya Rasayana) in Ayurveda: an update. Pharmacogn Rev 6(12): 147-153.

8. Murphy BM, Frigo LC (1993) Development, implementation, and results of a successful multidisciplinary adverse drug reaction reporting program in a university teaching hospital. Hospital Pharm 28(12): 1199-1204.

9. Ray S, Ray A (2015) Medhya Rasayanas in Brain Function and Disease. Med chem 5: 505-511.

10. Lakhan SE, Vieira KF (2010) Nutritional and herbal supplements for anxiety and anxiety-related disorders: Systematic review. Nutr J 9: 42.

11. Gamoh S, Hashimoto M, Hossain S, Masumura S (2001) Chronic administration of docosahexaenoic acid improves the performance of a radial arm maze task in aged rats. Clin Exp Pharmacol Physiol 28(4): 266-270.

12. Su HM (2010) Mechanisms of omega-3 fatty acid-mediated development and maintenance of learning memory performance. J Nutr Biochem 21(5): 364-373.

\section{Your next submission with Juniper Publishers will reach you the below assets}

- Quality Editorial service

- Swift Peer Review

- Reprints availability

- E-prints Service

- Manuscript Podcast for convenient understanding

- Global attainment for your research

- Manuscript accessibility in different formats ( Pdf, E-pub, Full Text, Audio)

- Unceasing customer service

Track the below URL for one-step submission https://juniperpublishers.com/online-submission.php 